\title{
The Development of Social Responsibility among Students in School: the Social Test Method
}

\author{
Elena Harlanova $^{1 *}$, Natalia Shirochenkova ${ }^{2}$, Oxana Yalakaeva ${ }^{2}$ and Liubov Ulyanova $^{3}$ \\ ${ }^{1}$ SUSHPU, Department of Social Work, Pedagogy and Psychology, Chelyabinsk, Russia \\ ${ }^{2}$ Middle School of General education №107, Chelyabinsk, Russia \\ ${ }^{3}$ SUSHPU, Postgraduate study, Chelyabinsk, Russia
}

\begin{abstract}
In the conditions of unstable modern community development we should secure our future. Thus, the issue of social responsibility among both individuals (citizens, representatives of different professions), and collective subjects (corporations, governments, states) becomes more and more relevant. In this article, taking into account the experience of Russian and foreign scientists, the methodology of the activity approach, social and active education and theories of positive action of the youth, we may reveal the potential of the social test method in the development of social responsibility among secondary school students. The peculiar feature of this method being applied consists in ensuring the students' voluntary participation in socially important activities. Moreover, these activities include the following discussion and feedback concerning their social responsibility (its value bases, the ways of demonstration and implementation, the effect on the participants and people around them) together with the consistently increasing authorship and social interaction experience in the course of analyzed activity.
\end{abstract}

\section{Introduction}

Modern science justifies the importance of human social responsibility e.g., according to H. Jonas. A person is responsible for the ability to live and for the human existence continuation [1]. Social responsibility changes its meaning: from the element of social action (here we mean the scheme: «value-action-responsibility») it turns into the principle of action before another main act (scheme: «value-responsibility-action-») [2]. Therefore, it is urgent to predict the consequences of both our actions and rejection of them that may lead to negative results.

\footnotetext{
* Corresponding author: harlanova_em@mail.ru
} 
While working over the issue of social responsibility development among citizens, the researchers consider the contribution of different levels of education: preschool [3], school [4], vocational education [5], adult education [6]. Besides, we should mention the role of informal education in the socialization of the individual [9].

Foreign studies on the topic of social responsibility dwell upon it as an ability that people possess to respond effectively and adequately towards their behaviors, in a way that the person adjusts to those norms that set all social behaviors [5]

The theoretical basis of this research is quite diverse: the theory of moral development based on cognitive psychology; the theory of moral socialization, which goes back to the psychology of learning. Besides, there is a large number of supporters and followers of the theory of positive action of young people.

Investigating that area, we developed a model for teaching personal and social responsibility (TPSR) based on the physical activity by D. Hellison. Nowadays it is being used successfully in physical education lessons in secondary schools to work with teenagers who are at risk of exclusion from school [10] or isolation [11]. This approach has even wider prospects of application in work with youth [12].

The impact on social responsibility covers a variety of methods: the presence of responsible jobs in the school [13], social planning (or project-making) [8], reading and discussing literature [5], the method of social action [14]. At the same time, the diversity of approaches and methods of influencing social responsibility even more emphasizes the importance of practice [7] allowing students to translate their concept of social responsibility into action. Co-education organized as a social activity at the system level also has the prospect of stable growth and integration [15].

At the present stage of researches we may assert the positive influence of methods and programs for the promotion of social responsibility on social and academic achievement of secondary school students [5]. Among other positive tendencies we have noticed the prevention of bullying in schools [13], improvement of attitudes and values of students [16]. In addition, we can reveal the interconnection between responsibility and pro-social behaviour, empathy, self-efficacy and opposition of responsibility and aggression as well [17].

However, the analysis of practice shows that the heads of educational institutions differ in their views on social responsibility. To be more exact, they are more sceptical if we take the heads of secondary schools [18]. Schools tend to value cognitive abilities more than any other skills, and some of them even disregard social responsibility [19].

In the works of Russian researchers $[2,20]$ social responsibility is considered not only as a normative behaviour (awareness of duty, the need to follow social norms, to resist violations of due), but also readiness to be included in socially significant activities (thus contributing to the social development). From the point of view of activity theory it is necessary to organize the process of education as a specific students' activity in its social, conscious-transformational and semantic structures, and this will inevitably ensure the formation of a responsible personality [21]. Likewise, socially active education in school [22] extends the students' participation in socially significant activities. At the same time, awareness and voluntary acceptance of the value of responsibility in a critical social time are quite hard to develop [23] in the period of youth.

\section{Purpose of the Study}

The aim of the study is to determine the potential, methodological and methodical basis for the application of the social test method. Consequently, it will ensure the development of social responsibility of secondary school students based on Russian and foreign approaches. 


\section{Methodological basis of the study}

The teaching staff of the innovative platform of secondary school № 107 in Chelyabinsk works on social responsibility increasing among students. Social responsibility is considered as a set of students' characteristics which are reflected in 1) his or her desire to make socially significant actions, 2) the ability to implement initiatives in practical transformative activities, 3) make responsible decisions based on the rational analysis of their actions [24].

In the course of the study, we turned to the social test method. According to M. I. Rozhkov, a social sample (or test) is a set of sequential activities related to the implementation of specifically organized social activities. They are based on the choice of behavior in this activity. This set also serves as a means of correlation of self-discovery and analysis of their capabilities in the spectrum of ongoing social functions [25].

The potential of social trial (test) aimed at the development of social responsibility consists in a number of abilities:

1) to obtain information about the social objects through interaction with other people (representatives of different social groups and professions, the subjects of responsibility),

2) to enrich their understanding of the social environment and the role of social responsibility in the solution of problems, choice of methods, activities and the analysis of its consequences,

3) to express and realize oneself as a subject of responsibility.

The methodological basis for the implementation of the method lies in the following issues:

1) psychological theory of activity, which define the frames and algorithm for the implementation of the method in the course of social responsibility development;

2 ) the concept of socially active education [20], which determines the requirements for the substantive and procedural aspects of the educational process;

3 ) the theory of positive action of young people and, in particular, the model of immersion into personal and social responsibility by Hellison [12], which sets the gradual development of values, norms in the process of applying the method of social tests.

\section{Methodology and course of research}

The definition of the methodological basis for the study of social responsibility development among school students sets the following requirements for the method application: 1) voluntary individual's choice of his behavior; 2) the implementation of a full cycle of activities in a socially active education; 3) discussion and feedback on the planned, implemented and accomplished activities from the sphere of social responsibility.

The condition of voluntary participation is provided by the choice of students, who define the group (which contains the sample), the relevance of these social samples. Also they are aware of the future instructions and ways to implement orders.

In the course of implementing the full cycle of activities we have elaborated the algorithm of the social test: 1) the choice of a significant topic; 2) the definition of the purpose and objectives of the work; 3) the development of a plan; 4) the distribution of assignments between the participants (individuals or micro-groups); 5) practical actions (collecting information, its transformation into a "product", the result of the activity and its presentation); 6) analysis of practical actions, 7) group discussion (feedback).

According to the ideas of socially active education, it involves purposeful, initiative, constructive, productive participation of education as a social institution in significant changes in the socio-cultural life of society [20]. Besides, socially active education includes urgent issues of the social environment, and the process of its organization is built as an 
interaction of subjects in order to transform the social environment by means of assimilated knowledge.

The content of social responsibility is successfully revealed in group discussions, in the course of planning, implementing and summarizing the activities organized on the basis of social tests method. We based our research on the model of teaching personal and social responsibility by D. Hellison [12] with 5 levels: 1) respect for the rights and feelings of others, 2) participation and effort; 3) personal autonomy; 4) leadership and assistance to others; 5) application of knowledge received beforehand.

In addition, we should mention the elements of socially dependent relations that structure any social responsibility: the subject of responsibility (who is responsible for the performance) - the authority of responsibility (the leader of the action) - subject of responsibility (the issue of the action) - sanction (how the participants respond). All the steps above allow us to capture the consistent deployment of social responsibility.

Next, let us consider the stages of implementation of the social tests method. Initially, as far as the student has not yet formed the necessary skills, it is important to perform in the sphere of his easiest development. In order to do this, we have to organize a group work with pedagogical support, then ensure the implementation of a full cycle of social activities and finally reveal the content of social responsibility.

In the first phase, the group is involved in the preparation for the case and the study, which is crucial and motivating for the group itself (e.g. dwell upon the questions: "What is valuable in this world?"", "Responsibility is a burden or a chance?", "The Story of Success"). The case is prepared together step-by-step through the discussion of values and meanings, setting goals and objectives, the forecast of consequences and the development of the plan, formulating the orders (areas of responsibility), self-control and mutual control in carrying out the tasks, analysis of the results (in external and internal sphere), discussion of the value basis of the activities carried out.

The content of the social responsibility discussion includes defining the concept, adopting the rules of interaction (respect for the rights and opinions of others, friendly attitude, participation and effort). At the same time, each student acts as a bearer of responsibility. He chooses the level of inclusion in the common activity, his own duty (the subject of responsibility) in the borders of the group (the authority of responsibility), and during the group discussion receives approval or disapproval (sanctions). The assignments include visits to certain social institutions (government, public institution, enterprise, kindergarten, etc.), meeting with people with different social roles, and gathering information in different ways (a map of observation, interview, conversation, photos, etc.).

As part of the review, students assess and self-evaluate actions for implementing the principles of responsibility and their impact on social well-being, relationships, and the overall effect of the project.

In the second phase, the group chooses an issue related to the problem relevant both for the members of the group and for the educational organization. It may be: the deterioration of students health; conflicts between students, increasing number of road accidents involving students; harmful eco-habits that aggravate the environmental situation in the school; aggressive actions of students, etc. The group accomplishes the entire cycle of activities based on the social test method as a team of authors, whilst the teacher acts as a consultant and assistant in the matter of resources.

The discussion of social responsibility is concentrated on two levels: personal autonomy and mutual support. Group members distribute responsibilities based on the participants' abilities. Thereby, the performers are to be guided not only by their desires, but also the need to perform their duty (the subject of responsibility). We may witness how the level of responsibility changes, as everyone is no longer a performer of the duty; it is also the subject and the receiver, so the sanctions are aimed not only at a particular group member, 
but also at the whole group (from gratitude to disapproval). The assignments are related to the study of the social phenomenon, its causes, the possibilities of organizing targeted influence, the preparation of the product-report and its demonstration.

Group discussion of the results, assessment and self-assessment bear the aim of understanding the level of social responsibility by students from the point of personal autonomy and mutual support.

The third phase requires the involvement of both school representatives and external social partners in the process of problem solving. At this stage, the social test method is implemented in collaboration with the method of social design (social projecting). Students in micro-groups (case groups) choose the issue, following the principle of social responsibility, work out its solution, involving other members of the group, partners, receiving advice from the teacher. The subject of responsibility gradually expands and becomes more complex, it includes functional roles with a variety of actions (communication with social partners, information promotion, work with a group of volunteers, etc.) rather than individual assignments.

The high level of responsibility is guaranteed by the team of organizers and recipients together with social partners and the organization (school) itself, which is represented by the team. The sanctions are also aimed at the member of the group, the whole group and the entire organization.

The activity mentioned above is accompanied by reflexive meetings, discussion of both the level of personal autonomy, assistance to others, and social responsibility manifested by students in other contexts.

\section{Results}

The implementation of the method of social tests has a constructive potential for the development of social responsibility among students. Social samples provoke emotional responses of students; they obtain a new way to get information and the new status to interact with others, while group feedback promotes the rationalization of social responsibility. It fully meets the demands of the social responsibility development, which pays special attention to the emotional factor and specifies the influence of the rational elements [21]. Students are included in the social tests, thus having the opportunity to learn the theoretical basis of the social responsibility, to become aware of its role in practice and to understand it as a value and a principle of activity.

\section{Conclusion}

If we dwell upon the development of social responsibility of students, the social test method, including a full cycle of activities and discussion of plans and results has an indisputable potential. The approbation of the method displays that the implementation of the method affects the emotional and sensual component of the individual, while group discussion and feedback contributes to the transformation of emotions into a rational understanding of social responsibility. The method lets the teenager discover the world of real social relations as an object of direct observation, study, interaction, and himself as a subject of these relations. This method may be more appropriate in programs of influence on the social responsibility of students.

\section{References}


1. H. Jonas, Global Ethics and Moral Responsibility: Hans Jonas and His Critics, (2016)

2. A. V. Belov, Izvestia VGPU, 9(36), 4-8, (2011)

3. S. K. Kharrazi, and Y. Delgoshaee, Cognitive approach towards education and its impact on social responsibility of pre-school children, (2010).

4. J. D. Alarcon, and E. Bellows, Imagining Elementary Social Studies: a Controversial Issues Reader, 3-24 (2018).

5. M. A. Carbonero, L. J. Martin-Anton, L. Otero et al., Frontiers in Psychology, 8, (2017)

6. R. Malinauskas, Croatian Journal of Education-Hrvatski Casopis Za Odgoj I Obrazovanje, 21(1), 189-212 (2019)

7. C. S. Liu, and X. D. Zhu, University Social Responsibility and Quality of Life: a Global Survey of Concepts and Experiences, 8, 223-234 (2017)

8. Y. I. Fagimovich and G. R. Gabdulvalieva,Proceedings of 6th World Conference on Educational Sciences, 191, 801-804 (2015)

9. E. Chernikova, N. Sivrikova, and T. Ptashko, SHS Web of Conferences: International Conference on Advanced Studies in Social Sciences and Humanities in the Post-Soviet Era (ICPSE 2018), 55 (2018)

10. A. Escarti, M. Gutierrez, C. Pascual et al., Spanish Journal of Psychology, 13(2), 667-676 (2010)

11. A. Escarti, R. Liopis-Goig, and P. M. Wright, Journal of Teaching in Physical Education, 37(1), 12-23 (2018)

12. T. Martinek and D. Hellison, Journal of Physical Education Recreation and Dance, 87(5), 9-13 (2016)

13. M. A. de la Caba-Collado, R. Lopez-Atxurra, and M. Bobowik, Revista De Educacion, 374, 183-206 (2016)

14. N. Siddiqui, S. Gorard, and B. H. See, Studies in Educational Evaluation, 61, 7482 (2019)

15. S. J. Zuiker, K. T. Anderson, and M.E. Jordan Learning Culture and Social Interaction 9, 80-94 (2016)

16. B. Martinez, A. Gomez-Marmol, A. V. Valenzuela et al., Espiral-Cuadernos Del Profesorado, 9(18), 16-26 (2016)

17. M. G. Sanmartin, A. E. Carbonell, and C. P. Banos, Psicothema, 23(1), 13-19 (2011)

18. C. Apaydin, and B. Ercan, Innovation and Creativity in Education, 2(2), 5590$5598(2010)$

19. M. C. H. Jukes, S. S. Zuilkowski, E. L. Grigorenko, Journal of Cross-Cultural Psychology 1, 82-98 (2018)

20. A. N. Agafonova, I. V. Yakhneeva, and I. N. Nikitina, European Proceedings of Social and Behavioural Sciences, 57, 1055-1068 (2019)

21. Z. A. Reshetova National Psychological Journal, 3(27), 40-55 (2017)

22. Gilmanov, S. A. Mishchenko, and V. A. Brattseva, Modern Journal of Language Teaching Methods, 10, 22-30 (2018)

23. M. G. Ivanov Psycho-pedagogical magazine Gaudeamus 1, 120-131 (2008)

24. A.A. Sevryukova and N. In. Sorochenkov Kazan pedagogical journal, 6, 121-126 (2018)

25. M. I. Rozhkov Yaroslavl pedagogical Bulletin, 1 (1994) 